\title{
Імплементація протоколів ERAS у хірургічному лікуванні кіст підшлункової залози
}

\begin{abstract}
Мета роботи: імплементація програми швидкого відновлення (ERAS) у хірургічному лікуванні кіст підшлункової залози. Матеріали і методи. Проведено аналіз хірургічного лікування 12 хворих із кістою підшлункової залози, яким було виконано лапароскопічну цистоєюностомію за Ру з приводу псевдокіст підшлункової залози, що сформувалась після перенесеного гострого деструктивного панкреатиту. У всіх пацієнтів використано періопераційну програму ERAS.

Результати досліджень та їх обговорення. Внаслідок використання програми ERAS тривалість операції в середньому склала $(172,23 \pm 53,30)$ хв, об’єм крововтрати до 100 - 150 мл, середній ліжко-день - $(3,92 \pm 0,92)$ доби, дренаж видаляли після контрольного УЗД дослідження на першу післяопераційну добу у всіх пацієнтів. У 8 пацієнтів перше випорожнення спостерігали протягом першої післяопераційної доби, у 4-х - протягом 2-ї після використання одноразово послаблюючої клізми. Ускладнень, пов’язаних з неспроможністю анастомозів, не спостерігали. Інтенсивність больового синдрому в першу і другу післяопераційну добу за допомогою ВАШ склало 5,25 і 3,5 бала, відповідно. У всіх оперованих пацієнтів були задовільні показники діастази. Нудоту в першу післяопераційну добу спостерігали в 3 пацієнтів, що одразу ефективно купірувалась введенням медикаментів. Блювання не спостерігали у жодного пацієнта. Протягом 1-го року всі пацієнти знаходились під наглядом з УЗД-контролем. Жодних віддалених післяопераційних ускладнень не виявлено.
\end{abstract}

Ключові слова: посилене відновлення після операції; підшлункова залоза; псевдокіста; цистоєюностомія.

Постановка проблеми і аналіз останніх досліджень та публікацій. Бурхливий розвиток та впровадження мініінвазивних методик в абдомінальну хірургію дав суттєвий поштовх до пошуку шляхів швидкого відновлення пацієнтів після операційного лікування. Ще в 1997 році H. Kehlet звернув увагу на чинники, що впливають на тривалість перебування хворого в стаціонарі після операції та можливості впливу медичного персоналу на ці чинники. [1]. Згодом він та D. Wilmore ввели поняття "fast track surgery" (хірургія швидкого відновлення) і розробили універсальні принципи для різного роду операційних втручань [3].

“Fast track" хірургія - це комплекс заходів, що зменшують стресову відповідь організму пацієнта на операційне втручання. Хірургічний стрес впливає на інтенсивність післяопераційного болю, нудоту та блювання після операції, катаболічні процеси в післяопераційному періоді, рухальну активність кишечника, зниження дихальної функції, підвищене навантаження на серцево-судинну систему, порушення балансу про- та антикоагуляційної системи, порушення водно-електролітного обміну, порушення сну [2, 5]. У 2001 р. у Лондоні зібралась наукова група для ретроспективного вивчення факторів, що впливають на подовжене перебування хірургічного хворого в стаціонарі, та розробки шляхів швидкого відновлення організму пацієнта після операційних втручань. Згодом дана наукова група запропонувала нову назву замість Fast track surgery. Вони запропонували назвати комплекс заходів із швидкого відновлення функцій організму хірургічного хворого - ERAS (enhanced recovery after surgery - пришвидшене відновлення після хірургічного втручання), що $є$ найбільш вживаною на сьогодні [1]. ERAS - це мультимодальна періопераційна програма, розроблена на основі доказової медицини, яка дозволяє якісно скоротити час відновлення після операційного втручання та повернутись до високої якості життя. Основними постулатами для ERAS є: мініінвазивність хірургічного втручання. Зменшення довжини операційної рани прямо пропорційно зменшенню хірургічної травми, а, значить, і зменшенню стресової відповіді організму на втручання; відсутність до- та післяопераційного голодування (зменшення проявів післяопераційного катаболічного процесу, раннє відновлення перистальтичного навантаження під час операції (зменшення навантаження на помпову діяльність серця); локальна та регіонарна анестезії (зменшення інтенсивності післяопераційного болю); оптимізоване медикаментозне забезпечення протягом перебування в стаціонарі (використання антиеметиків, глюкокортикоїдів, атибіотико- та тромбопрофілактики) $[1,4]$.

Матеріали і методи. У період із листопада 2012 по листопад 2018 р. на клінічній базі кафедри загальної хірургії № 2 Національного медичного університету імені О. О. Богомольця - Київський міській клінічній лікарні № 3 було прооперовано 12 хворих з кістою підшлункової залози. Всім па- 
цієнтам було виконано лапароскопічну цистоєюностомію (ЛЦЄС) за Ру під комбінованою загальною анестезією.

Вік хворих становив від 36 до $54(46,8 \pm 6,7)$ року. Співвідношення чоловіків та жінок було 5 до 7 (41,66 \%) і (58,34 \%). У всіх хворих було встановлено діагноз псевдокісти підшлункової залози, що сформувались після перенесеного гострого деструктивного панкреатиту. За даними проведених КТ у пацієнтів товщина стінки кісти була в межах 3-5 мм, а розміри в найбільшому вимірі досягали 14 см, але не були менше 6 см.

Ми використовували ERAS протоколи для хірургії підшлункової залози, запропоновані міжнародною спілкою ERAS [4], але з деякими винятками та доповненнями.

Хворі були обстежені в амбулаторному порядку і надходили в стаціонар безпосередньо в день операції.

\section{Передопераційний період.}

Інформування пацієнта. Напередодні обговорили технічні деталі операційного втручання, особливості раннього післяопераційного періоду, можливі післяопераційні ускладнення, а також дали відповіді на всі питання, які цікавили пацієнтів, так досягали комплаєнс хворого.

Антибіотикопрофілактика. Добову дозу антибіотика вводили парентерально за 1 год до операційного втручання. Наступну та останню дозу через 24 год. Для антибіотикопрофілактики використовували Цефуроксим в дозі 1,5 г на добу.

Підготовка кишечника. Для механічної очистки кишечника ми використовували осмотичні проносні препарати. Клізми в якості підготовки кишечника до операціїі ми не використовували.

Харчування (виключення голодування). За 2 год до операції хворий випивав 200 мл теплого солодкого чаю. За день до операції до 18.00 пацієнти притримувались звичайного режиму харчування. 318.00 при прийманні осмотичних проносних речовин - питний режим.

Премедикацію 3 використанням наркотичних аналгетиків не застосовували.

Профілактика післяопераційного болю та післяопераційного парезу кишечника. За годину до початку операції усім хворим встановлювали катетер у перидуральний простір (ПДК) за стандартною методикою.

Інтраопераційний період.

Використання комбінованої (інгаляційної та внутрішньовенної) аналгезії.

Редукція хірургічного стресу. За 10 хв до першого розрізу внутрішньовенно болюсно вводили Дексаметазон 16 мг.
Мінінвазивність операційного втручання. Ми виконували ЛЦЄС із використанням 5 троакарів, розташованих типово. Всі троакарні доступи попередньо були знеболені Бупівакаїном з проведенням місцевої інфільтраційної анестезії. На операційний стіл пацієнта вкладали на спину з розведеними ногами, оперуючий хірург стояв між ніг пацієнта, асистенти з обох боків. Після обробки операційного поля через голку Вейреша виконували пневмоперитонеум двоокисом вуглецю під тиском 12 мм рт. ст. Відеопорт (10 мм) встановлювали над пупком, також встановлювали ще 4 порти: 1 (12 мм) в лівому мезогастрії та 3 (10 мм) окремо в правому мезогастрії, лівому та правому підребер'ї. Якісну візуалізацію органів черевної порожнини досягали завдяки використанню лапароскопічного обладнання (HD-відеокамери Karl Storz ). Після виконання лапароскопії та виявлених зрощень після перенесених попередніх операційних втручань та перенесених запальних процесів черевної порожнини, що потребують хірургічної корекції, виконували вісцеролізис за допомогою гармонічного скальпеля Ultracision (Ethicon Endosurgery). Доступ до кісти підшлункової залози виконували шляхом пересічення шлунково-ободової зв'язки за допомогою LigaSure ${ }^{\circledR}$ (Covidien) (рис. 1).

Шлунок піднімали догори, проводили подальшу мобілізацію кісти підшлункової залози від задньої стінки шлунка, застосовуючи гармонічний скальпель Ultracision, та готували вільну площину поверхні кісти підшлункої залози розмірами 4-5 x 3-4 см для формування цистоєюноанастомозу.

На наступному етапі великий сальник і поперечно-ободову кишку за допомогою граспера від-

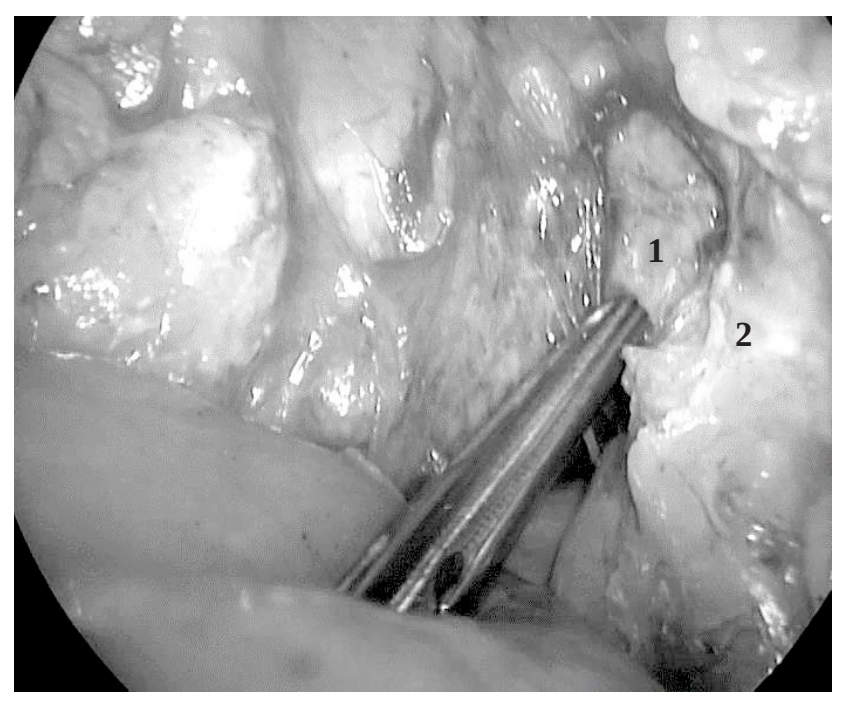

Рис. 1. Розсікання шлунково-ободової зв'язки: 1-кіста підшлункової залози; 2 - розсікання шлунковоободової зв’язки. 
водили догори для візуалізації зв'язки Трейтца. Відступивши 25-30 см від дуоденоєюнального переходу брижу тонкої кишки гармонічним скальпелем Ultracision розсікали до кореня. Тонку кишку перетинали лапароскопічним лінійним степлером Echelon Flex 60 (Ethicon).

Відступивши 35-40 см дистальніше місця перетину кишки накладали ентеро-ентероанастомоз “бік в бік”. Формування апаратного ентеро-ентероанастомозу починали з ентеротомії за допомогою гармонічного скальпеля Ultracision, iї виконували на одному рівні до 0,5 см у поздовжньому напрямі до привідної та відвідної кишок по протибрижовому краю. У подальшому через сформовані отвори заводили бранші зшивального апарата Echelon Flex 60 мм на глибину 3-4 см (колір касети синій) та формували задню губу анастомозу. Передню губу анастомозу формували так: спочатку накладали 3 наскрізні вузлові шви атравматичною ниткою (вікрил 3.0) на передню губу анастомозу, використовуючи їх в якості “трималок”. У подальшому за допомогою граспера під час одночасної тракції “трималок” доверху накладали нижче них апарат Echelon Flex 60 мм (колір касети синій) та остаточно формували передню губу ентеро-ентероанастомозу.

Цистоєюноанастомоз у всіх випадках формували позаду ободової кишки. Для цього через виконаний за допомогою гармонічного скальпеля Ultracision поздовжній отвір завдовжки 3-4 см правіше від судин брижі поперечно-ободової кишки у безсудинній зоні проводили Ру-петлю та підводили до місця цистоєюноанастомозу, намагаючись уникнути будь-якого натягу.

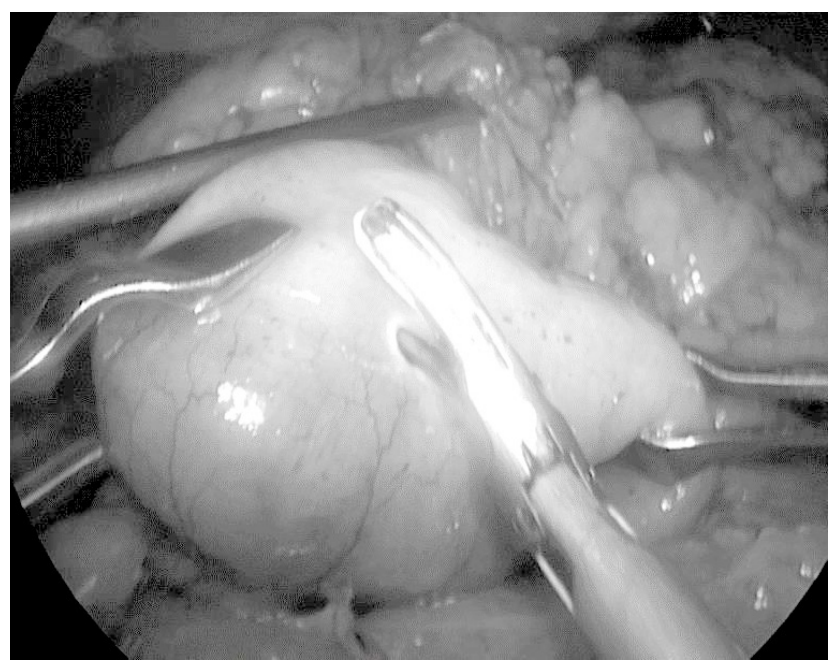

Рис. 2. Формування отвору в Ру-петлі для бранші зшивального апарата за допомогою ультразвукових ножиць Harmonic Ace (Ethicon Endosurgery).
3 метою запобігання внутрішній грижі дефект брижі поперечно-ободової кишки закривали перервним вузловим швом (вікрил 3.0).

Для формування цистоєюноанастомозу накладали 1-2 серо-серозні шви “трималоки” між стінкою кісти та Ру-петлею в напрямку селезінки на 1,5-2 см вище майбутньої степлерної лінії шва також відступаючи 1,5-2 см від лінії попереднього степлерного шва кукси Ру-петлі. Накладені серосерозні шви між стінкою кісти підшлункової залози та Ру-петлею використовували для тракції та зіставлення при виконанні наступних етапів формування анастомозу. Гармонічним скальпелем Ultracision на одному рівні виконували ентеротомію та цистотомію до 0,5-0,7 см у поперечному напрямі (рис. 2).

Тканину стінки кісти підшлункової залози забирали на гістологічне дослідження, вміст кісти аспірували.

У сформовані отвори на глибину 4-5 см заводили бранші лапароскопічного лінійного степлера Echelon Flex 60 мм (колір касети синій) та формували задню губу цистоєюноанастомозу (рис. 3).

Передню губу цистоєюноанастомозу формували однорядним безперервним швом (пролен 3.0). Операцію закінчували санацією черевної порожнини (рис. 4).

4. Запобігання гіпотермії. Під час операції тіло хворого підігрівали за допомогою циркуляції теплого повітря в матраці в межах $38-42{ }^{\circ} \mathrm{C}$.

5. Дренування. Всім хворим встановлювали дренаж через троакарний отвір у правому підребер’ї до ЦЄА.

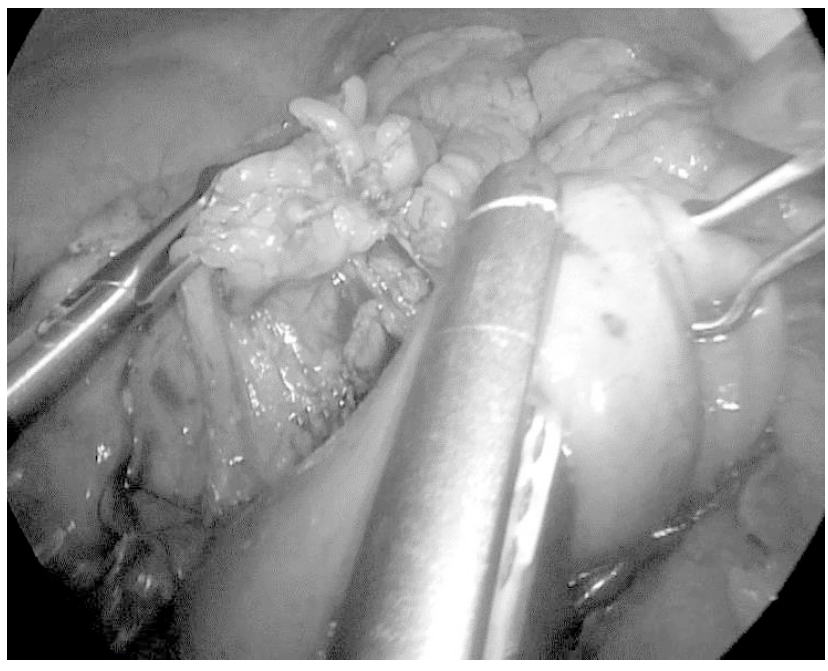

Рис. 3. Формування задньої губи цистоєюноанастомозу механічним степлерним швом. 


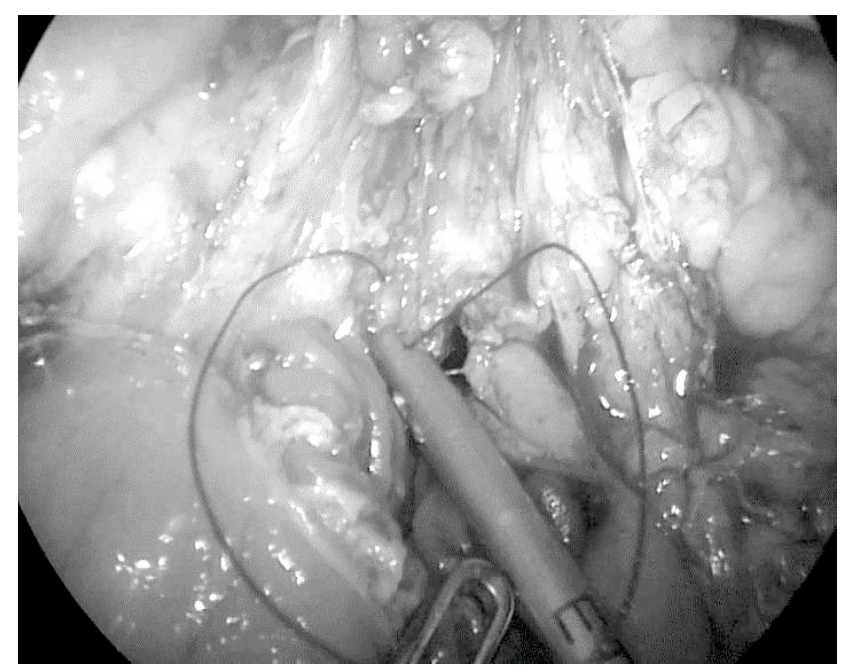

Рис. 4. Формування передньої губи цистоєюноанастомозу однорядним безперервним швом за допомогою Vicryl 3-0.

6. Використання сечового катетера. Сечовий катетер використовували у всіх випадках (встановлювали після інтубації трахеї), видаляли після екстубації при досягненні хворим адекватного рівня свідомості.

7. Використання назогастрального зонда. Ми не використовували назогастральний зонд для декомпресії шлунка в післяопераційному періоді.

\section{Післяопераційний період.}

Рання активація пацієнтів. Через 2 год після екстубаціїі ми переводили пацієнта у вертикальний стан. Пацієнт сідав на ліжку, потім - ставав на ноги починав рух на місці. Через 6 год після операціїї - ходьба в межах палати.

Запобігання голодуванню. Через 4 год - приймання рідкої їжі. Хворому давали 250 мл адаптованої білкової суміші з ароматизаторами (шоколад, ваніль). Наступного дня вранці - адаптована білкова суміш, в обід - рідкий овочевий суп, ввечері - вівсяна каша на воді.

Активація рухової активності кишечника. Для цього ми використовували планове введення анестетика в ПДК.

Профілактика болю. Вводили анестетик у ПДК за потреби та НПЗП.

Тромбопрофілактика. Кожному хворому призначали компресійний трикотаж інтраопераційно та 1-2 доби після оперпації до повного відновлення рухової активності в межах відділення. Окрім того, введення парентерально низькомолекулярного гепарину.

Профілактика нудоти та блювання. Перша доба - планове використання Ондасетрону парентерально, 2-га доба - за потреби.
Профілактика неспроможності цистоєюноанастомозу. Хворим призначали блокатори протонної помпи та аналоги соматостатину. Перше введення після формування ЦЄА, потім до другої післяопераційної доби.

Дренаж. На наступну добу після операції проводили контрольне УЗД черевної порожнини. При відсутності виділень по дренажу та ознак накопичення рідини в черевній порожнині дренаж видаляли.

Критерії виписування. Відсутність післяопераційних ускладнень як інтраабдомінальних, так i з боку післяопераційної рани, наявність самостійного випорожнення, відсутність підвищеної температури тіла, відсутність скарг пацієнта.

Результати досліджень та їх обговорення. Тривалість операції в середньому становила $(172,23 \pm 53,30)$ хв, а об'єм крововтрати не перевищував 100-150 мл. Показники післяопераційної діастази не перевищували норми. Раннє післяопераційне ускладнення виникло в однієї пацієнтки, в котрої виникла кровотеча з лінії швів ентеро-ентеро анастомозу на 2-гу добу післяопераційного періоду, що потребувало додаткового консервативного лікування та подовження періоду перебування в стаціонарі до 8 діб. Ускладнень, пов'язаних з неспроможністю анастомозів, не спостерігали.

Середній ліжко-день склав $(3,92 \pm 0,92)$ доби.

Дренаж видалявся після контрольного УЗД дослідження на першу післяопераційну добу. Критеріями видалення дренажу були: відсутність виділень по ньому та відсутність ознак накопичення рідини в ділянці ЦЄА за даними УЗД дослідження. У 8 пацієнтів перше випорожнення було протягом 1 післяопераційної доби, у 4-х - протягом 2 після використання одноразово послаблювальної клізми.

Ми оцінювали інтенсивність больового синдрому в першу і другу післяопераційну добу за допомогою ВАШ (рис. 5).

Нудоту в першу післяопераційну добу спостерігали у 3 (25 \%) пацієнтів, що одразу ефективно купірувалась введенням Ондасетрону. На 2 післяопераційну добу нудоту спостерігали лише в однієї пацієнтки. У жодного пацієнта не спостерігали блювання.

Протягом 1-го року всі пацієнти знаходились під наглядом. Кожні 3 місяці їм проводили УЗДконтроль. Жодних віддалених післяопераційних ускладнень не виявлено. 3 пацієнти ще досі знаходяться під нашим контролем. 


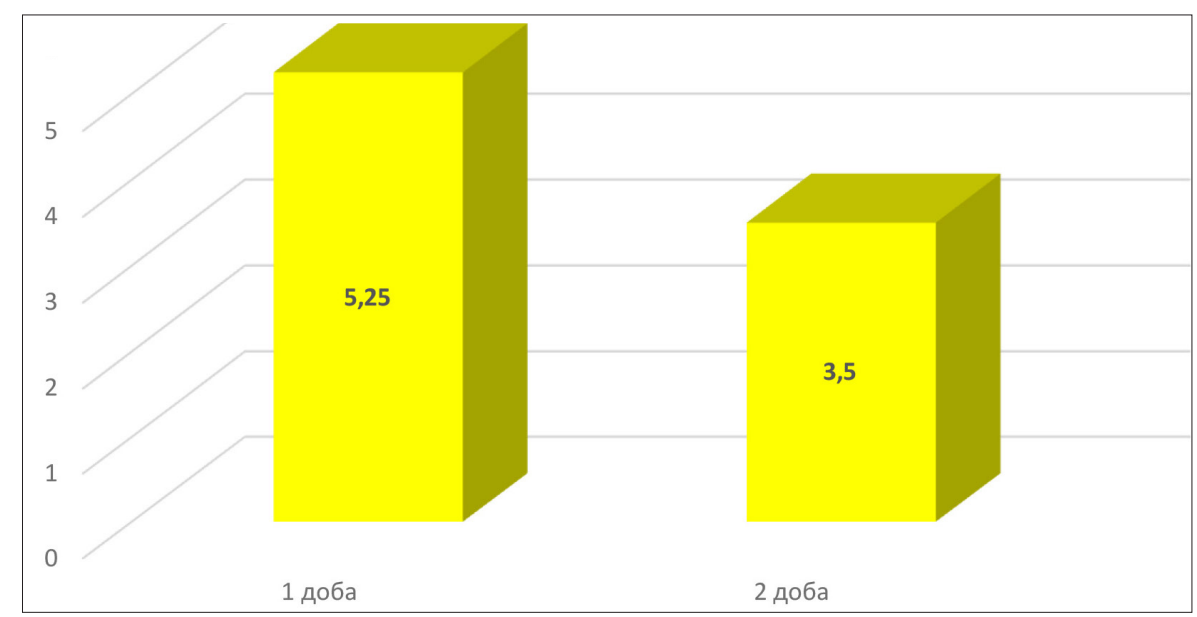

Рис. 5. Рівень інтенсивності післяопераційного болю за ВАШ.

Висновки. Імплементація ERAS-протоколів дозволяє суттєво знизити час перебування пацієнта в стаціонарі та повернути йому прийнятну якість життя в короткі строки. Це наш перший досвід спроби імплементації даної програми в панкреатичну хірургію непухлинних захворювань підшлункової залози. Основним напрямом дії даних протоколів $є$ зниження інвазивності втручання, профілактика післяопераційного болю, нудоти та блювоти. Всі вище перераховані фактори є наслідком відповіді організму пацієнта на хірургічне втручання, інакше кажучи - стресова відповідь. Дія на всі ланки стресової реакції дозволяє пришвидшити реабілітацію хворого.

ERAS програма - $\epsilon$ продуктом доказової медицини. Всі її ланки були підтверджені на високому рівні наукової доказовості. Імплементація цих прин-

\section{СПИСОК ЛІТЕРАТУРИ}

1. Ljungqvist O. ERAS - Enhanced recovery after surgery / O. Ljungqvist // Journal of Parenteral and Enteral Nutrition. 2014. - No. 38. - P. 559-566.

2. Wilmore D. W. From Cuthbertson to fast-track surgery: 70 years of progress in reducing stress in surgical patients / D. W. Wilmore // Ann. Surg. - 2002. - Vol. 236, No. 5. - P. 643-648.

3. Kehlet H. Evidence-based surgical care and the evolution of fast-track surgery / H. Kehlet, D. W. Wilmore // Ann. Surg. -

\section{REFERENCES}

1. Ljungqvist, O. (2014). ERAS - enhanced recovery after surgery. Journal of Parenteral and Enteral Nutrition, 38, 559-566.

2. Wilmore, D.W. (2002). From Cuthbertson to fast-track surgery: 70 years of progress in reducing stress in surgical patients. Ann. Surg,, 236 (5), 643-648.

3. Kehlet, H., \& Wilmore, D.W. (2008). Evidence-based surgical care ципів вимагає від хірурга рішучості, адже необхідно відмовитись від таких знайомих і багаторічних традиційних програм періопераційного ведення хворого. На нашу думку, впровадження ERAS програми в повсякденне життя хірургічного відділення в Україні $€$ необхідним і корисним. Звичайно, наші умови можуть диктувати деяку адаптацію протоколів, що рекомендовані міжнародним товариством, але основні постулати - мініінвазивність, використання мультимодальної аналгезії, запобігання тривалому голодуванню хворого - повинні бути незмінними. Протягом останнього десятиріччя нам вдалось впровадити в повсякденну роботу майже всі ERAS програми, що присвячені загальній хірургії. I вони, дійсно, показали надзвичайну ефективність в швидкій, а головне - якісній реабілітації пацієнтів після загальнохірургічних операційних втручань.

2008. - Vol. 248, No. 2. - P. 189-198.

4. Fast-track surgery could improve postoperative recovery in radical total gastrectomy patients / Fan Feng, Gang Ji, Ji-Peng Li [et al.] // World J. Gastroenterol. - 2013. - Vol. 19 (23), No. 6. P. 3642-3648.

5. Barton J. G. Enhanced recovery pathways in pancreatic surgery / J. G. Barton // Surg. Clin. North Am. - 2016. Vol. 96 (6). - P. 1301-1312

and the evolution of fast-track surgery. Ann. Surg., 248 (2), 189-198. 4. Fan Feng, Gang Ji, \& Ji-Peng Li (2013). Fast-track surgery could improve postoperative recovery in radical total gastrectomy patients. World J. Gastroenterol., 19 (23), 6, 3642-3648.

5. Barton, J.G. (2016). Enhanced recovery pathways in pancreatic surgery. Surg. Clin. North Am., 96 (6), 1301-1312.

Отримано 31.07.2019 
O. YU. IOFFE, O. P. STETSENKO, YU. P. CURA, M. S. KRYVOPUSTOV, M. M. STETS

O. Bomolets National Medical University, Kyiv

\title{
IMPLEMENTATION OF ERAS PROTOCOLS IN THE SURGICAL TREATMENT OF PANCREATIC CYSTS
}

The aim of the work: implementation of the enhanced recovery after surgery (ERAS) in the surgical treatment of pancreatic cysts. Materials and Methods. The analysis of surgical treatment of 12 patients with pancreatic cyst was performed. All patients underwent laparoscopic cystojejunostomy according to Ru due to pancreatic pseudocyst, which was formed after suffering acute destructive pancreatitis. ERAS was used during perioperative period.

Results and Discussion. Due to the usage of ERAS, the duration of surgery averaged (172.23 \pm 53.30$)$ minutes, blood volume loss up to $100-150 \mathrm{ml}$, average bed-day - (3.92 \pm 0.92$)$ days, drainage was removed after the control ultrasound study on the first postoperative day in all patients. In 8 patients, the first bowel movement was noted during the 1st postoperative day, in 4 patients - during the 2nd after the use of a single attenuating enema. There were no complications related to anastomotic failure. The intensity of the pain syndrome in the first and second postoperative days with the use of VAS was 5.25 and 3.5 points, respectively. All operated patients had satisfactory diastasis rates. Nausea in the first postoperative day was noted in 3 patients, who immediately purchased effective medication. Vomiting was not observed in any patient. During the 1-st year, all patients were monitored with ultrasound. No distant postoperative complications were detected.

Key words: enhanced recovery after surgery; pancreas; pseudocyst; cystoyostomy

А. Ю. ИОФФЕ, А. П. СТЕЦЕНКО, Ю. П. ЦЮРА, Н. С. КРИВОПУСТОВ, Н. М. СТЕЦЬ

Национальный медицинский университет имени А. А. Богомольца, Киев

\section{ИМП.ЛЕМЕНТАЦИЯ ПРОТОКОЛОВ ЕRАЯ В ХИРУРГИЧЕСКОМ ЛЕЧЕНИИ КИСТ ПОДЖЕЛУДОЧНОЙ ЖЕЛЕЗЫ}

\begin{abstract}
Цель работы: имплементация программы быстрого восстановления (ERAS) в хирургическом лечении кист поджелудочной железы.

Материалы и методы. Проведен анализ хирургического лечения 12 больных с кистой поджелудочной железы, которым была выполнена лапароскопическая цистоеюностомия по Ру по поводу псевдокист поджелудочной железы, которая сформировалась после перенесенного острого деструктивного панкреатита. У всех пациентов использовали периоперационную программу ERAS.

Результаты исследований и их обсуждение. Вследствие использования программы ERAS продолжительность операции в среднем составила $(172,23 \pm 53,30)$ минут, объем кровопотери до $100-150$ мл, средний койко-день - $(3,92 \pm 0,92)$ сутки, дренаж удаляли после контрольного УЗИ в первую послеоперационную сутку у всех пациентов. У 8 пациентов первой стул отмечено в течение первых послеоперационной суток, в 4-х - в течение второй сутки после использования однократно слабительной клизмы. Осложнений, связанных с несостоятельностью анастомозов, не было. Интенсивность болевого синдрома в первую и вторую послеоперационную сутки с помощью ВАШ составило 5,25 и 3,5 балла, соответственно. Во всех оперированных пациентов были удовлетворительные показатели диастазы. Тошноту в первую послеоперационную сутки отмечали у 3 пациентов, что сразу эффективно купировали введением медикаментов. Рвоту не наблюдали ни у одного пациента. В течение первого года все пациенты находились под наблюдением УЗИ-контроля. Никаких отдаленных послеоперационных осложнений не выявлено.
\end{abstract}

Ключевые слова: усиленное восстановление после операции; поджелудочная железа; псевдокиста; цистоеюностомия. 